\title{
Applied realism, American grand strategy, and strategic interests in the European balance
}

Text of working paper, presented at the Center for Security Studies, ETH Zürich, on the 20 ${ }^{\text {th }}$ of October, 2021. Lead discussant Dr Henrik Larsen.

To cite: Maitra, S. "American grand strategy and strategic interests in the European balance”, discussion paper, CSS, ETH Zürich, October, 2021.

To understand the American grand strategy in Europe, one must start with the British imperial grand strategy. The fundamental aims of British foreign policy throughout history were fairly simple, to preserve trade and sea routes, to maintain overwhelming naval power to guard against any seaborne invasion as well as to ensure "gunboat diplomacy" if need be, as an "offshore balancer", and finally to ensure that there's a disunited European continent, in the sense that there is no unified hegemon or ideological/theological entity, under one flag and one army. The logic was predicated on realism. If the continent was dominated by one power, the overwhelming aggregate power, demographic, economic, and military, would be too much for any maritime great power to balance, and the littorals could be used to potentially launch an invasion across the seas. Post-British empire, the American grand strategy emulated these basic tenets with some minor tinkering. The difference was, in how these aims were achieved.

And it is here, I would like to point out, a very instructive episode from British history, which elaborates the strategic interests. Lord Palmerston said in 1864, "I am sure every Englishman who has a heart in his breast and a feeling of justice in his mind sympathizes with those unfortunate Danes," when German troops were massing at Danish borders. Britain, if you remember, had a treaty guarantee to Denmark, far, far stronger than it had with Belgium in 1914. But Palmerston ended with saying, "We did not think that the Danish cause would be considered as sufficiently British, and as sufficiently bearing on the interests and the security and the honour of England, as to make it justifiable to ask the country to make those exertions which such a war would render necessary." Now, this might sound poetic and amoral, but overall, it was basically a strategic decision. Britain knew that it cannot escalate within the continent, without a land war that it might lose as the Germans can counter-escalate. Second, border changes within the continent, won't affect the broader British power as long as the basic balance of power is ensured, as Britain would still remain a naval hegemon, despite German power within the continent, as the littorals were not affected. Both those lessons Britain forgot in 1914, but that is a different story for another day.

Now, Americans do not do grand strategy in imperial terms, as you all remember from John Kerry's bizarre "this isn't the $19^{\text {th }}$ century" remark, during the Ukraine crisis. But Americans understand the balance of power, exactly the way Britain did, given that American strategy unwittingly mirrors imperial Britain. Instead of offshore balancing, however, Washington follows a primacy or power 
maximising strategy in Europe. But that has created a dilemma for both American policymakers and is fundamentally opposed by an overwhelming number of Americans, which seems to be increasing, with the rise of populism. American policymakers are perpetually dissatisfied with the security architecture arrangement in Europe.

Consider, that West Germany itself had 12 divisions in 1989. But all that has now atrophied, alongside European muscle because of two reasons. One, institutionalising NATO and EU. And two, American hard power remaining and, in some cases, expanding in Europe. Institutionalising NATO was by design, not a flaw, to not only ensure that there were no great power challengers in Europe, and that Germany stayed down, but also, in Barry Posen's words, to spread the institutions of "liberal hegemony". For those of you who study Russian military literature, for example, will see that the Russians see no difference between NATO, EU, and Germany, and the US. In fact, for those of you remember, one of the first Germans who wanted NATO enlargement, much before the Clinton government was ready, was Volker Rühe. As Barry Posen reminded us, Germans did not initially see the NATO enlargement as spreading liberal values, which is a new spin, they saw it strategically, as to move their frontiers further east, towards Russia. It was no different than imperial German designs over the Balkans, and the Baltics. These are not my words, but the logic is observable.

On the other hand, a continuous primacist military presence in Europe was considered a constant burden by every post-war American president, at odds with pre-war American character and small government republicanism, and has reflected in the rhetoric of Presidents Eisenhower and Kennedy, to Bob Gates, Ash Carter, Barack Obama, to Donald Trump. Likewise, while the average American electorate is not quite isolationist, they are neither imperial and are increasingly disinterested in European security. The interplay of these two opposing instincts, with the changing geopolitical scenario of Europe, brings us to the next point. American foreign policy discarded conservative realism, and doubled down on institutionalising European peace, and that in turn failed to resolve the basic foreign policy dilemma faced by any maritime great power, just how much should one get involved, without being tied down.

So, primacy isn't working as a grand strategy in Europe and has run its course. What then, is to be done? I argue that there are two theoretical directions observable. One, retrenchment and offshore balancing, with minimal footprints, and two, divide and rule and balance of power. Retrenchment is of course a valid strategy, to recuperate and restructure. In a recent study, Joseph Parent and Paul MacDonald studied instances when great powers retrenched or doubled down and found that momentary fallback leads to conservation and husbanding of resources for future great power confrontations. But American restrainers are not sure how that retrenchment will work out and what an intelligent retrenchment strategy would look like. Barry Posen, Stephen Walt and other realists argued that the US should start naming the SACEUR to be a European, and move all troops out from anywhere east of Thames; to have the Europeans decide on infantry, armour, logistics, and other issues, while the US takes care of Air cover as well as naval and nuclear deterrence. That is a reasonable idea. But this is not the $19^{\text {th }}$ century, and a handful of people do not get to decide foreign policy in this democratic age (much though realists would prefer that), and it is practically impossible to order a full American retrenchment from Europe, or to sell that to American policymakers, a fundamentally liberal activist media, and the general public. On the other hand, leaving Europe to its own, which would lead to a European hegemon, which might or might not side with China on trade, is out of the question. While average Europeans do not want to take part in a Sino-American cold war, the European policymakers, except maybe, France, are totally 
wedded to American security, PESCO, and other initiatives notwithstanding. One should remember that a weak Austro-Hungarian empire was enough to support Germany that led to war. An EU, untethered from the US, siding with China on trade and other issues, against the US, would result in the collapse of more than five hundred years of Anglo-American grand strategy. Frankly, that is not going to happen.

So, I argue, that the potential realist American grand strategy would entail a middle ground between buck-passing/retrenchment, and divide and rule. America should ideally discourage all NATO and EU expansion. There cannot be a grand strategy for an entity that is constantly mutating and expanding its boundaries, while being increasingly dependant on American security umbrella, blood and treasure. The borders of the region in question should be finite. Second, America would potentially ensure a favourable balance of power within the continent and even within EU, playing different sides, instead of institutionalising. Structural necessities will make it even more logical. For too long institutionalising has resulted in sanctimonious free riding in the west and evangelical smaller powers in the east. The trendlines of an ascending movement of "realism and restraint" in DC, however, indicate that American policymakers will eventually look at propping up nation states which are favourable to the US, instead of an EU-wide strategy. Applied realism suggest that that would result in the US propping up various powers within the EU, to share burden and elevate them. That would mean, there would be competition among the European powers on who can be genuine allies to the US, and policy-wise that would entail special status, weapons platforms and privileged military sales, cultural exchanges, training, and joint operational platforms and doctrines, and financial and material aids.

Second, the military atrophy will be only reversed if Europe realises that Uncle Sam will not be there immediately in case of an emergency. America would potentially, therefore, encourage more pre First World War type alliances, smaller in structure and coherent in strategy, very similar to AUKUS, or the Greco-French alliance. If the UK, Poland, and the Baltic nations have special defence treaties and arrangements under the American security umbrella and within the security architecture of NATO, it relieves the US from taking a disproportionate burden and forward presence. Likewise, a Greco-French naval policing of the Mediterranean and Aegean is a net benefit for the US, to focus on other theatres. Policy-wise, for example, the US should encourage Poland and the Baltic states to form brigade and division-size patrolling battalions, with operational leadership under British or French command. Bilateral ties are likewise welcome. It would also potentially break the Brussels/Berlin duopoly on strategic directions as well as encourage rapid military build-up in Paris and London which will in turn deter Moscow. Overall, if the US intends to maintain a preponderance in the European balance, finding allied powers to share even a portion of the security burden, without absolute retrenchment, is the only way forward, at a minimal cost, to American taxpayers.

- Dr. Sumantra Maitra is a national-security fellow at the Center for the National Interest; a nonresident fellow at the James $G$ Martin Center; and an elected early career historian member at the Royal Historical Society. His latest paper is titled "NATO Enlargement, Russia, and Balance of Threat", published in the summer edition of the Canadian Military Journal, Dept of National Defence, Canada. He can be reached on twitter, @MrMaitra. 


\section{NOTES}

This is a text of a speech which deals with broad grand strategic themes, so language is deliberately unacademic. Any typographical or grammatical errors, however, are solely mine. British spellings are used, unless quoted otherwise.

No explanations for phrases and concepts such as "security dilemma", "offshore balancing", "primacy", "divide and rule", "power maximising", and such are given here, as it is expected that this is to be circulated among practitioners and theoreticians, who are already cognizant of the relevant concepts.

A list of relevant literature, however, is as follows.

1. "What Europeans think about the US-China Cold War", ECFR https://ecfr.eu/publication/whateuropeans-think-about-the-us-china-cold-war/

2. "Europe Can Defend Itself", IISS Survival https://www.tandfonline.com/doi/full/10.1080/00396338.2020.1851080

3. "The Case for Offshore Balancing", Foreign Affairs https://www.foreignaffairs.com/articles/unitedstates/2016-06-13/case-offshore-balancing

4. "Should the United States leave NATO?" Segment from a round table co-hosted by the Center for the National Interest and Charles Koch Institute https://www.youtube.com/watch?v=GjIINyDEH0A

5. "Twilight of the Titans: Great Power Decline and Retrenchment" https://www.cornellpress.cornell.edu/book/9781501755309/twilight-of-the-titans/

6. "NATO Enlargement, Russia, and Balance of Threat" Canadian Military Journal, Department of National Defence, Canada https://nottingham-repository.worktribe.com/output/5811164/natoenlargement-russia-and-balance-of-threat 